\title{
St. Anthony of the Floating Larynx
}

We take a train to Padua to see the Giottos, lapis and gold, and the mostly-destroyed Mantegna frescoes of the life

of St. James, blown to bits by a wayward American bomb, patched together like a puzzle now, but with most of the pieces missing.

My friend is on a pilgrimage to the Cathedral of St. Anthony of Padua, patron saint of harvest, lovers, sick animals,

and lost objects, oggetti in Italian, and this church is quite an Oggetto itself, with a capital "O,"

and I have seen my share of shrines in the last three months. Immediately I recognize that this is no ordinary repository

of frescoes, plastic statuary, and other divine bric-a-brac. It is a hive of religiosity, alive with bizarre reliquaries;

in fact we stand in line to see St. Anthony's larynx, yes indeed, his voice box, suspended in a gelatinous scarlet liquid,

a cartilaginous snake of animal matter, from which my husband (educated by Jesuits) turns, white as a piece of typing paper.

This is the Italy I dreamed of, saints, snakes, gypsies, cutthroats in a baroque tutu of religion and sin.

The venality of it all is like eating cake for breakfast, though it's obvious that not much cake eating is going on

in the Cathedral of St. Anthony but rather atonement for cake eating, for three quarters of the multitude in the church

are on their knees, reminding me of a Billy Graham Crusade I attended as a twelve-year-old when the great man himself said, 
"Fall down on your knees and pray for God's forgiveness." It's an interesting concept, forgiveness, and one, I must say,

that appeals to the throng in Padua, or are they praying for miracles? In a sense forgiveness is a miracle, or at least

for someone like me who finds pardon difficult and unfulfilling, or as my friend Mary Ann Wolf used to say, "What good's a grudge

if you can't hold it?" What would St. Anthony have to say about mercy? I wonder as I queue up with my friend at the saint's tomb.

She wants a husband and I want back the bag that Alitalia lost three months ago in Rome. As I raise my arm to place my palm on

the wall of the tomb, a four-by-four grandmother dressed in black cuts in front of me and knocks my arm out of the way.

Her problem is probably a lot more pressing than a suitcase of dresses, which, by the way, St. Anthony delivers to me

a month later in the Miami airport. My friend is still single, although her old boyfriend called and told her she was

the love of his life. Not exactly her dream come true but in the true-love ballpark. Maybe the saints do better

with material requests. A green silk dress has got to be easier to deliver than a boyfriend with a job and a working personality.

Metaphysics is so tiring, which is what St. Anthony would probably say if he could, lying in that tomb, sans larynx, teeth,

and assorted other body parts. Day after day, we line up with our problems, raise our troubled palms. "Maria? No, my friend, she's

wrong for you. It won't last more than a year." And the poor guy goes off, thinking, That Maria, I could really be happy with her. 